\title{
On Globalization
}

\author{
I/I/I/I/I/I/II Charles Hanly \\ University of Toronto \\ (Canada)
}




\section{Resumo}

É impressionante como, num curto período de tempo, o site da internet "Facebook" fortaleceu o conceito de McLuhan sobre "aldeia global" com o de "lugar de encontro" e ainda criou as bases potenciais para a existência de uma vizinhança global. Todos os principais avanços em tecnologia da comunicação fizeram do mundo, desde McLuhan, algo muito mais aldeão do que foi antes, mesmo no tempo de McLuhan duas décadas atrás. Mas a globalização é um processo e é preciso compreender sua estrutura e seu dinamismo à maneira dos analistas que procuram, com o intuito de melhorar a vida dos indivíduos, entender a psique humana. Pode, pois, a psicanálise contribuir para a compreensão da aldeia global? Podemos ter a esperança de que a aldeia global formada pelas tecnologias comunicacionais nos pacifiquem e nos unam?

\section{Palavras-chave}

Aldeia global, tecnologia da comunicação, Facebook e Freud.

\section{Abstract}

The internet site "Facebook", in a stunningly short time, has supplied McLuhan's "global village" with a "meeting place" and creates the potential for a global neighbourhood. All the major developments in communications technology since McLuhan have rendered the globe more of a village than it was, even in McLuhan's day only two decades ago. But Globalization is proceeding. We need to understand its structure and dynamics just as we, as analysts, seek to understand the structure and dynamics of the human psyche to find realistic ways and means of bringing about benefits for the lives of individuals. Is there something that psychoanalysis can contribute to our understanding of the global village? Dare we hope that the global village being formed by communications technology will pacify us as it unites us?

\section{Key-words}

Global village, communications technology, Facebook and Freud. 
My late University of Toronto colleague, the English scholar and guru of communications theory, Marshall McLuhan, gave the expression "global village" its modern popular use to name the results in our daily experience of the capacity of television to provide us with images of events happening anywhere in the world. McLuhan's popularity in intellectual and cultural circles was evident in his cameo role in Woody Allen's film “Annie Hall”. Television brought the skirmishes, the battles, the devastation, the wounded and the dead of the Vietnam War into the living rooms of the world as it was happening and nourished the anti-war movement in the U.S. and elsewhere. Television was an enormous step forward in creating "world public opinion" which now has to be taken into account by the political leaders of nations - the first beginnings of a global village in which what neighbours would think has a new cogency and efficacy. It is likely that the next presidential election in the U.S. will be significantly influenced by who Americans believe can best restore the reputation of the U.S. in the world.

McLuhan's communications theory was prophetic of subsequent communications technology developments, still undreamed of during the era of the television revolution, that have made the globe even more akin to a village. Even earlier, Freud (1930) drew a prescient picture of modern man as a prosthetic god; a god who has recently been equipped with a global telephone, messaging, photographic, television, entertainment and computer capability in his pocket. The internet site "Facebook", in a stunningly short time, has 
supplied McLuhan's "global village" with a "meeting place" and creates the potential for a global neighbourhood. All the major developments in communications technology since McLuhan have rendered the globe more of a village than it was, even in McLuhan's day only two decades ago.

McLuhan was building on the ideas about communication technology in the rise and fall of empires he received from the economic historian Harold Innis (1950), also a professor at the University of Toronto. Innis documented the role of papyrus and writing in making it possible for Rome to become the administrative centre of a vast empire that more or less encompassed the then known world turning it into an early global village "policed", I would add, by Roman legions sufficiently well to bring about the pax romana.

Innis recognized that communications technology was but one of a group of factors at work in globalization. The basic factor bringing nations into relations with each other is economic. From early history, a country with a surplus of certain goods but in need of others would seek to find the needed goods among its neighbours. By trading their surplus goods for needed goods that are in surplus in a neighbour, countries can establish reciprocally beneficial trade relations that are compatible with peace i.e. acquisition by trade rather than conquest. Mutually advantageous trade that provides the necessities of life and its desired enhancements promotes a better motivated peace among nations than Roman legions. Trade, however competitive, so long as it falls short of trade war deliberately designed and carried out to damage others, provides the most secure foundation we have for the formation of international groups of good neighbours unified by real mutual advantage because of real differences. The current opposition to economic globalization is aimed at powerful international corporations in wealthy countries that are looking for labour at lower costs. It is seen, by the political left, to be a form of capitalist colonial exploitation of the poor and weak by the wealthy and powerful. There is an unavoidable market exploitation of workers in the sense that international corporations manufacturing in Asia must be able to profitably produce goods at a cost in wages that will meet the costs of constructing plants, supplying machines and the transportation of manufactured products to markets in Europe and the Americas at competitive prices. The consequence of this state of affairs is that the labour cost of global 
manufacturing must be lower than the labour cost of manufacturing in Europe or the Americas. This labour cost should include decent working conditions, but it may not, if providing European and American standards of working conditions make the off-shore manufacture or service unprofitable.

Surplus (economically unnecessary and, perhaps even in the longer term unprofitable) exploitation of labour can occur when globalizing businesses and industries, with the cooperation of the government of the country in which they are located, fail to provide affordable wages and working conditions that would still allow profitability. I do not know what steps Latin American countries are taking to use trade relations to bring diplomatic or economic pressure to bear on these problems. The current Canadian government has a history of pressuring countries with which we have trade relations about workers rights and human rights generally. For example, last week far reaching economic sanctions against the government of Burma for its abuse of political rights have been announced by the Canadian government. Canada's current prosperity and the rapid rise of the Canadian dollar have been caused in no small part by the need of China and India for Canadian technology and natural resources. The government has used these mutually dependent trade relations to apply pressure on the Chinese government to improve freedom of the press, political rights and workers rights and conditions. But Canada has relied on diplomacy, probably, to no particular effect and has not made the availability of our natural resources conditional upon improvements of civil liberties in China. The American global company Google has accepted Chinese censorship as the price for gaining access to its vast computer market in the rationalizing and, perhaps, cynical hope that its presence will eventually have a leavening, beneficial influence.

However, to the extent that the world is becoming a global village on account of communications technology, individual citizens of the global village can exert an influence of their own on global corporations which crosses national boundaries and is independent of governments. We can be responsible citizens of the global village by identifying rogue global corporations and refuse to purchase the goods and services they sell. Communications technology can help us identify rogue corporations, make choices and encourage others to do the same. Diamond (2005), the author of the Pulitzer Prize 
winning synthesis of natural and social science Guns, Germs and Steel, out of concern for the impact of our methods of production and transportation on the environment and recognizing that we are now living in a global village stated that “...there is no other island/ other planet to which we can turn for help, or to which we can export our problems" (2005, p.521) and recommends that we as individual citizens of the global village can do some constructive things about the problems of our environment. We cannot directly influence, for example, logging companies that permanently deforest and turn huge tracts of land into unredeemable waste land. But he points out that "the reason that increasing numbers of logging companies are adopting sustainable logging practices is that consumer demand for wood products certified by the Forest Management Council exceeds supply. Of course, it is easiest to influence companies in your own country, but in today's globalized world the consumer has increasing ability to influence overseas companies and policy-makers as well" (2005:.556). Diamond's recommendation applies equally to human rights issues in the conduct of global manufacturing and business. Globalization is proceeding. We need to understand its structure and dynamics just as we, as analysts, seek to understand the structure and dynamics of the human psyche to find realistic ways and means of bringing about benefits for the lives of individuals. More precisely, we need to encourage social scientists, the Jared Diamonds of our communities, to understand the structure and dynamics of our global village so that we can, learning from them, make our contribution to the solution of its problems.

Is there something that psychoanalysis can contribute to our understanding of the global village? Unhappily, conquest and colonization by means of military or economic invasion has been, historically, the all too common alternative to trade as a means of acquiring the means of survival, prosperity and the accoutrements of human vain-glory. The Roman imperial bureaucracy may have been able to instruct and organize their satraps in Europe, Asia Minor and North Africa because of papyrus and writing, but the satraps and the peoples they governed were controlled by the Roman legions. The use of television, the press and the schools to control information in the Soviet empire could not preserve it as soon as the Red Army could no longer afford to supply its units with the resources it needed to operate effectively over large distances. 
Diamond (1999) has described the contributions of guns, germs and steel to conquest throughout history and, especially, their role in the conquest of the Americas by our European ancestors. The facts of history, and especially the history of the twentieth and, thus far, the twenty-first centuries, raise a fundamental question about human nature in the global village (Hanly, 1966). Can human nature sustain an equitable, stable, global peace in the global village based on cooperation and mutually beneficial work?

Freud (1921) implicitly raised this question when he differentiated artificial groups that require a leader and natural work groups based on a shared wish in circumstances in which its satisfaction requires cooperation. During the era of the mobile threshing machine Ontario's farmers, who typically and proudly worked their farms themselves, worked together to meet the demands of the harvest without leadership or direction other than their common needs, shared circumstances and a tradition of how to collectively meet the special labour demands of the grain harvest. We are familiar with the human capacity to share the work of rescue and reconstruction when natural disasters strike. But combines have eliminated the need for cooperative harvesting. And we cannot rely on natural disasters to sponsor cooperation. Russell (1949) having been struck by the cooperation and sacrifice of nations in the Second World War mobilized by the threat of Nazi Germany entertained the "Star Wars" speculation that all nations might be able to live peacefully together, if they were unified by a common purpose out of fear of an extra-terrestrial conquistador bent on subduing, evangelizing, enslaving and exploiting the earth's population. Russell appreciated how unrealistic such a hope was. But his speculation was a measure of our despair about world peace; the desperate stratagems needed to ensure it and, by implication, the extent of the danger within posed by human aggression. It is worth reminding ourselves of a striking contradiction in the thought of the enlightenment philosopher Kant. Kant (1795) advocated a league of nations bound by a covenant, mutually agreed upon, against war among them. Yet (Kant, 1790) exalted the general, who leads the youth to war, over the diplomat who negotiates a merely commercial peace because the general is the symbol of the highest and purest form of the moral categorical imperative to be dutiful even at the sacrifice of your own life. Freud (1933) would have been entitled to use this 
contradiction as evidence of the problems posed by the demands of the death instinct in the lives of individuals.

Dare we hope that the global village being formed by communications technology will pacify us as it unites us? Is such a hope realistic? If we can get to know each other better globally by the use of film and the new communications technologies, as we now do in the Americas by means of film albeit with sub-titles, should not sympathetic understanding of each other world wide sustain a mutually advantageous, competitive but peaceful cooperation? Is modern communications technology opening up new opportunities for the realization of a utopian condition different from but reminiscent of Rousseau's "state of nature" or Marx's "classless brotherhood of man"?

Freud (1921) clarified the psychological problem that is generated by the idealizing identifications at work in artificial groups. The residues of love and hate from Oedipal and sibling ambivalence are split with love going to the leader of the group and its members while hate is directed toward some other group. In artificial groups, peace within is secured by enmity without. Nation states are artificial groups. Thatcher knew from instinct, history and political experience, if not from psychological insight, that a war can awaken primitive enthusiasms and attachments that she could use to reverse her failing domestic political fortunes. The Argentinean invasion of the Malvinas fell into her lap. She declared war and won re-election. Ironically, Galtieri had the same motive for invading the Falklands. Before us we have, once more, the spectacle of waves of popular enthusiasm for war with young men dying in battle as a result of the greed for power of their national leaders and the pent up aggression of the citizens of two countries turning them into nationalistic enemies.

But may we not have stumbled on a hope for peace in the very nature of the global village. If the global village could replace the world of nation states, there would no longer be a nation for another nation to select as an object for its displaced aggression by a threatened leader seeking to curry favour with his/her citizens by means of a "just" war offering opportunities of the "moral" heroism of Kant's (1785) Categorical Imperative. Unfortunately, removing objects of hostility does not placate the hostility any more than repressing an impulse annihilates its affect. Other paths and other objects for hostile impulses and their heady satisfactions would have to be found. If international conflicts were to subside as a result of 
a waning of nationalism, other group formations would arise within the global village that would facilitate displacement of hostility. Communications technology can link us to each other and help us to know each other better, but it cannot guarantee that the link will be peaceful rather than hostile. Muslim terrorists use the latest communications technology to organize suicide bombings of western cities while Western countries use the same technology to identify and arrest them. Aggression is a biological instinct finding expression in a psychological drive. Communications technology can do nothing to modify this fundamental fact of human nature. There appears to be no grand transformational remedy, only a difficult and hazardous search for solutions to problems as they arise by means of which, one hopes, some progress in the arts of conflict resolution short of war can be made.

The strength of the wish for a transformational remedy for human aggression is evident in Freud's (1933) wishful idea in his letter on war to Einstein that evolution and the civilizing process has made pacifism constitutional - at least in Einstein and himself. Freud (1933) envisaged a "community of men who ... [subordinate] their instinct life to the dictatorship of reason" (1993: 213). However, it is questionable as to whether constitutional pacifism is consistent with Freud's death instinct theory (Siegel, 1979) and evolution could not bring constitutional pacifism about without Lamarck's untenable inheritance of acquired characteristics. Are we not limited to Freud's (1933) indirect methods of curbing aggression with aim inhibited love for and identification with others?

Perhaps the development of multiculturalism within countries will contribute toward peace in the global village because it tends to diminish some of the excesses of nationalist feeling and facilitate affectionate attachment to and identification among those who are different. Canada's Governor General, Michaelle Jean, in a recent keynote address to the XXV!! Latin American Studies Association International Congress in Montreal said, "I belong to all of the Americas. The history of these lands courses through my veins. It has been etched in my memory; it has left its mark on my body; it has shaped my vision of the world". Our Governor General performs the functions of the British Queen's representative in Canada but does so with her head and heart in and of the Americas. Her ancestors were African slaves. She was not born in Canada. Her family came 
to Canada when they were forced to flee the Haitian dictatorship 40 years ago. She gained her position in Canadian public life by her intelligent and fair minded chairing of a talk show on public affairs television in French. Her predecessor was a Canadian woman of Chinese origin who, like Michaelle Jean, had gained national prominence by chairing a television talk show on public affairs. Michaelle Jean concluded her remarks, "Globalization requires us to redefine our ties on a continental basis". The choice of Michaelle Jean as Governor General of Canada is indicative of a growing acceptance of the global village in Canada and of our place in the larger global village of the Americas and the world.

To exploit Plato's (Republic) metaphor psychoanalysis views the individual psyche as a global village in the sense that the mature psyche, after resolving inevitable conflicts, has established good neighbour relations among the three agencies of which it is formed and with reality. Film is one of the art forms that can nourish and facilitate this desirable homeostasis of the psyche that enables us to deal creatively with the problems of life. I am grateful for the opportunity to learn more about Brazilian film making and its relation to psychoanalysis. It is an opportunity for creative reciprocity. These initiatives of Brazilian film artists and psychoanalysts are a model for similar activities throughout the IPA.

Finally, the IPA also contributes in another way to the development of a global village. We are members of a global scientific community in which we can share our professional identity across political and cultural boundaries. The IPA is the only international scientific/professional organization that sets standards of training, practice and ethics for psychoanalysts no matter where on the globe they may be. The members of the IPA have recently reaffirmed this role with the adoption of the revision of training standards constituted by the three training models plan. Psychoanalysts make a contribution to the evolution of a peaceful global village when we accept differences and creatively use them to advance our science and to improve our therapy for the benefit of mankind. 


\section{Bibliografia}

DIAMOND, J. 1999. Guns, Germs and Steel. New York:

W.W. Norton.

2005. Collapse: How Societies Choose to Fail or Succeed.

New York: Penguin Group.

FREUD, S. 1921. Group psychology and the analysis of the ego.

S.E., 18: 69-134.

1930. Civilization and its discontents. S.E., 21: 64-145.

1933, Why war? S.E., 22: 199-215.

HANLY, C. 1966. A psychoanalysis of national sentiment.

In: Nationalism in Canada, ed. Peter Russell,

Toronto: McGraw-Hill.

INNIS, H. 1950). Empire and Communication. Lanham, Md.:

Rowman \& Littlefield, 2007.

JONES, E. 1955. The Life and Work of Sigmund Freud, vol. 2.

New York: Basic Books

KANT, I. 1790. The Critique of Judgement.

Trans. J.C. Meredith, Oxford: Clarendon Press, 1952.

1795. Toward Perpetual Peace and Other Writings on

Politics, Peace and History. Ed. Pauline Kleingeld,

New Haven: Yale University Press, 2006.

1785. The Moral Law. Trans. H. J. Paton,

London: Hutchinson University Library, 1947.

McLUHAN, M. (1962), The Gutenberg Galaxy; the Making of Typographical Man.

PLATO. 1993. The Republic. Trans. A.D. Lindsay.

London: E.P. Dutton.

SEGAL, H. 1979. Melanie Klein. New York: Viking Press. 